News and views

\title{
The Gothic Murals of the Church of the Holy Cross and St. Catherine of Alexandria in Nebovidy, Czech Republic
}

\author{
Kateřina Dvořákováa ${ }^{*}$ \\ aPrivate authorized expert, Absolonova 73, 62400 Brno, Czech Republic
}

\section{ARTICLE INFO}

\section{Article history:}

Received: 6 December 2010

Accepted: 20 January 2011

\section{Key words:}

religious architecture

Romanesque architecture

Gothic architecture

Gothic wall painting

dating

interpretation

\begin{abstract}
$A B S T R A C T$
The church in Nebovidy existed as early as the $13^{\text {th }}$ century and written references are first found in the $14^{\text {th }}$ century. In approximately the second third of the $14^{\text {th }}$ century the church was rebuilt for the first time. The nave was arched with late gothic tracery vaulting (two fields and three embossed keystones) in the next phase of rebuilding, beginning at the end of the $15^{\text {th }}$ century. In 1821 a new south entrance hall and a staircase were added. A roof and a tower destroyed by fire also required repairs.

The interior was entirely ornamented in honour the St. Catherine of Alexandria ( $14^{\text {th }}$ century). The main theme of the painting cycle consists of illustrations of St. Catherine's mystical engagement to Jesus
\end{abstract} Christ, and how her life became one with the life of the Saviour.

\section{Introduction}

The Church of the Holy Cross in Nebovidy u Brna can be proud of the unique and highly praised Gothic wall paintings. Dated to the $14^{\text {th }}$ century, the paintings are closely connected to the Luxemburg period, and to the Moravian court during the reign of Jobst, Margrave of Moravia, the later German King, and as the elected heir apparent was also known as the King of the Romans.

\section{Methodology of field work}

\subsection{A brief history of Nebovidy}

The first written reference to the village is found in the deed of donation of the Třebíc monastery in the Kosmas chronicle of 1104. At that time the Moravian Princes Oldřich (the Prince of Brno) and Litold (the Prince of Znojmo) founded the Benedictine monastery of the Ascension of the

"Corresponding author. E-mail: k-dvorakova@volny.cz
Virgin Mary, in Třebíč, to which it was donated. Nebovidy prospered in the $14^{\text {th }}$ century, and included a mansion with a church. The larger portion of Nebovidy was owned by Jan of Žatčany, and was traded by his heirs to Peter Hecht of Rosice, in exchange for the village Ostrov u Bíteše. In 1366 the Brno chapterhouse obtained his manor. They bought the remaining part of the village in 1381 from Ješek of Křižínkov. The village was subsequently influenced by numerous external historical events, generally connected to the history of Moravia, such as the Hussite wars, the Thirty Year's War, the Swedish plunder in 1645, the Habsburg monarchy, a fire in 1821 , both world wars and the formation of the Czech Republic in the $20^{\text {th }}$ century. The village of Nebovidy is located $5 \mathrm{~km}$ southwest of Brno city centre.

\section{Discussion of practical results}

\subsection{Church}

The dominant feature of the municipality is a church situated by the main road on a hill in the upper village. The original dedication of the church is thought to have been to the feast of St. Catherine of Alexandria (November $25^{\text {th }}$ ), and is now 


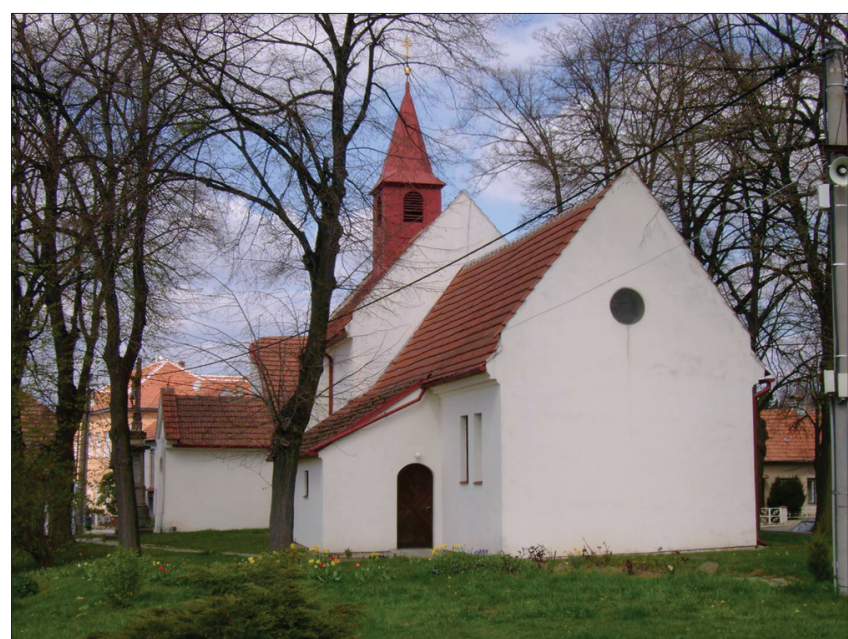

Figure 1. The Church of the Holy Cross in Nebovidy. (Authors: Kateřina Dvořáková, Martin Hotárek)

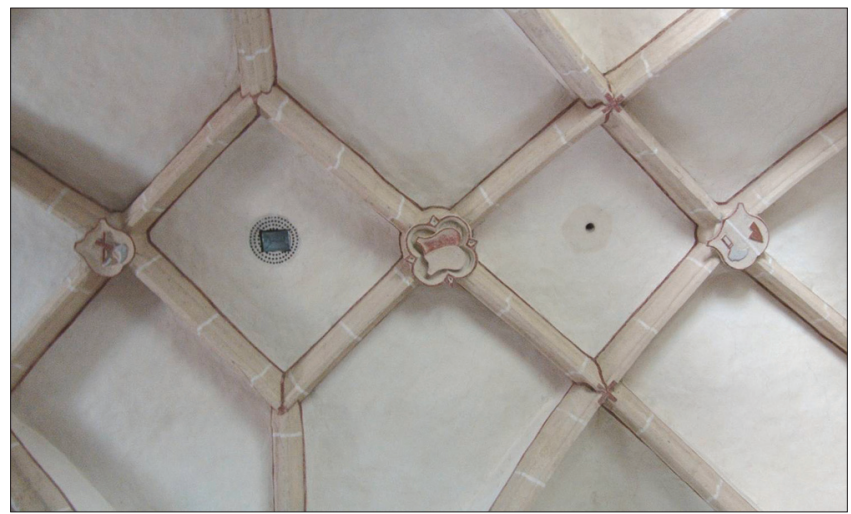

Figure 2. The vault in the nave. (Authors: Kateřina Dvořáková, Martin Hotárek)

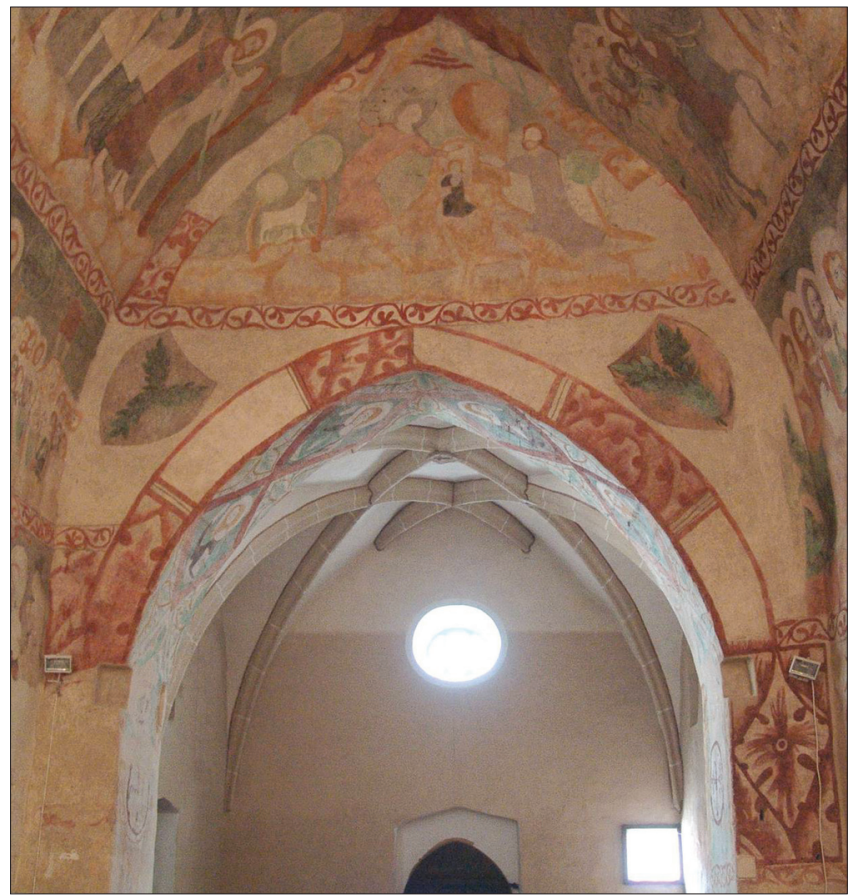

Figure 3. Painting on the wall of the gable of the triumphal arch with the exceptional scene of Isaac's Sacrifice. (Authors: Kateřina Dvořáková, Martin Hotárek) dedicated to the celebration of the Finding of the Holy Cross (May $3^{\text {rd }}$ ). The building has a rectangular ground plan, oblong chancel, and a single nave with a belfry and two bells at the western end (one bell was caste by Frantisek Hiller in 1822 to celebrate St.Wenceslas, the other was financed by Martin and Magdalena Pilát in 1943).

While we assume that the church in Nebovidy existed as early as the $13^{\text {th }}$ century, written resources only start to mention it from the $14^{\text {th }}$ century. The original contract between Provost Jan Munk, and the Brno chapterhouse, documents that it became a parish church in 1329 due to the merit of the brothers Mikuláš and Peter of Nebovidy.

The initial phase of the church's construction included an oblong nave with a non-arched ceiling and a simple chancel. Its appearance has not been preserved. In approximately the second third of the $14^{\text {th }}$ century the church was rebuilt for the first time. The original chancel was torn down and replaced by an oblong presbytery with a rectangular end and cylindrical apex vault. Today the outer quoin pillars document the extent of the original area from the medieval period. A lancet arch with widely open jamb of bricks forming pieces in the

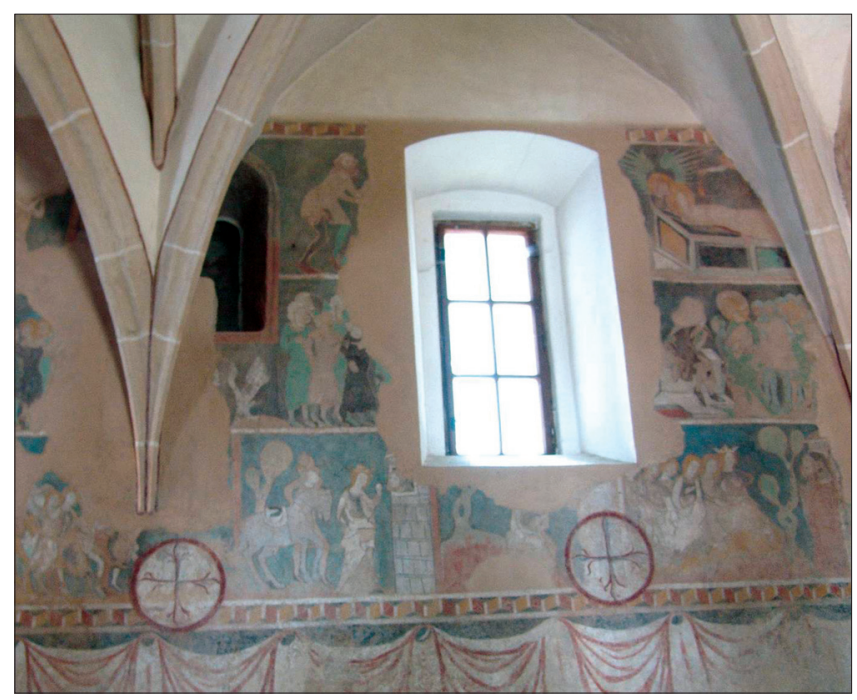

Figure 4. Legend of St. Catherine of Alexandria. (Authors: Kateřina Dvořáková, Martin Hotárek)

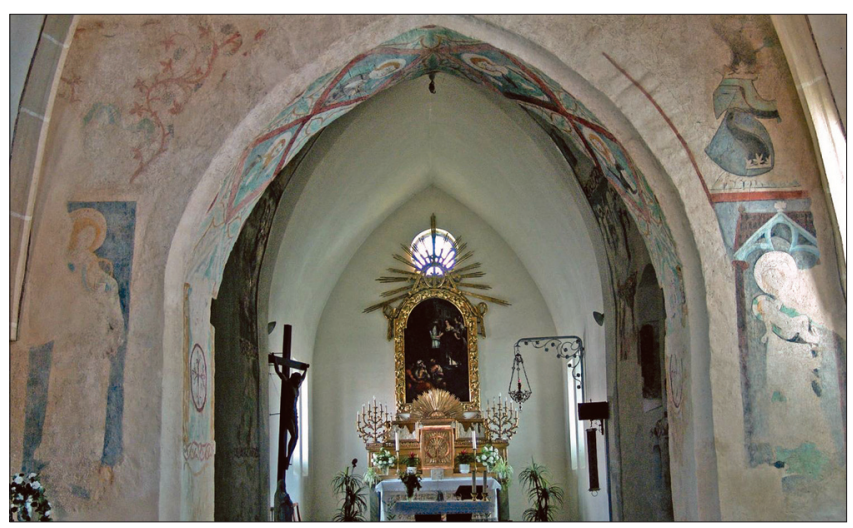

Figure 5. St. Catherine of Alexandria and the Virgin Mary with Child, on the triumphal arch. (Authors: Kateřina Dvořáková, Martin Hotárek) 
western wall of the church nave also originated from this period.

In the next reconstruction at the end of the $15^{\text {th }}$ century the nave was arched with late gothic tracery vaulting (two fields and three embossed keystones). The keystones carry embossed imagery, mainly paintings of viticultural and agricultural tools, along with the wine knife and wine chisel symbol of the village in the heraldic colours of Moravia.

A triumphal arch separates the nave from the chancel. On the right side behind the triumphal arch there is an entrance into the old sacristy decorated with a low saddle backed gothic portal with a stone jamb. In 1936 the old sacristy with barrel vaulting was connected with a new one that has a flat top wall and a rectangular ground plan.

In 1821 a new south entrance hall and a staircase were added to the church. A roof and a tower destroyed by fire also required repair.

\subsection{Gothic wall paintings}

During reconstruction of the electrical system in 1991 Nebovidy native Josef Bartl discovered an unusually extensive and unique set of Gothic wall paintings on the walls of the nave and the presbytery. Between 1992 and 2007 the paintings were investigated, recorded and conserved by the Moravian conservator and academic painter František Sysel.

The paintings were prepared "al secco" on a dry rendering with earth pigments, mainly ochre (yellow and red) and gemstones (malachite, azurite). The medieval painter also used lime white and lead white. The entire ornamentation of the interior was meant to honour St. Catherine of Alexandria. The main them of the painting cycle illustrates St. Catherine's mystic engagement to Jesus Christ and her life became one with the life of the Saviour. The paintings in the presbytery of the church nave are divided into four chords. The painted drapery always decorates the lowest chord of the paintings.

\subsubsection{Paintings in apse}

The oldest Gothic paintings from the 1360's are preserved in the church apse. We can admire the paintings both on the triumphal arch and on the north and south walls. The front wall of the chancel hasn't been preserved, because the whole east wall, probably including the gothic paintings, was torn down in 1936 when the church was renovated and a sixmetre extension added to the chancel.

We start with a view of the paintings illustrating the Old Testament. Uniquely preserved paintings on the wall of the gable of the triumphal arch illustrate the exceptional scene of Isaac's Sacrifice, which are a prevision of Jesus Christ's birth and sacrifice. Under that are the coats of arms of unknown donators. The paintings continue on the surface of the presbytery's north wall, where we can see the scenes from the Christological cycle (apart from some fragments from the cycle of legends concerning St Catherine in the second bottom chord), including, Jesus Christ's Entry into Jerusalem, Jesus Washing Peter's Feet at the Last Supper, Jesus Christ Appearing Before the Twelve Apostles (Doubting Thomas sees Jesus Christ's wounds).
On the south wall of the chancel we can see mainly the Passion scenes. In the top chord: Jesus Christ Before Pilate, The Disrobing of Jesus Christ, Ecce Homo, The Flagellation, and Christ Bearing of the Cross. In the third chord we see: The Crucifixion, The Descent from the Cross, The Entombment, Christ Resurrection, Noli me tangere, and Ascension Day. A painted drapery decorates the bottom chord of the paintings (it decorates the sedilia and sanctuary), in the second chord of the paintings there is a scene of the dream of St. Catherine of Alexandria (the Virgin Mary with little Jesus appear)

\subsubsection{Painting on triumphal arch}

The inner walls of the triumphal arch are decorated by figures of four saints - given the presence of aureole they are probably evangelists - inserted into decorative rhombic frames decorated by flower ornaments, also from the 1360s.

\subsubsection{Church nave}

On the sidewalls of the nave there is a legend cycle of paintings from the $1380 \mathrm{~s}$, corresponding to the original division of the nave into male and female sides. While the battle scenes with knights on horses on the southern wall of the nave cannot be definitely determined, the painting on the north wall shows the cycle of the legend of St. Catherine of Alexandria.

The first, bottom chord, is decorated with a painted drapery separated from the next chord by the motive of a wrapped ribbon. Rectangular frames separate the next three chords of figurative paintings on the north wall which picture the legend of St. Catherine of Alexandria. The first extant picture of the second chord of paintings on the north wall starts with the King's company, servants and a dog leaving the palace behind the town gates. The next scene is the story of Princess Catherine visiting a hermit who tells her about the greatness and glory of Jesus Christ. Catherine betroths to Jesus and in a mystical vision she is baptised by the hermit. In the last picture is the princess with her ladies-in-waiting and filled with the Holy Ghost. In the third chord of paintings St. Catherine is standing in front of the palace, with an aureole, together with her mother and her suitor, in whom we can recognise the suppliant son of the emperor himself. Following this is a scene of a procession and the arrested saint appearing before emperor Maximinus sitting on a throne. In the upper chord the kneeling saint appears before an instrument of torture (fragment). In the next picture is her executioner and in the final scene her burial, with bowing angels. Above this final chord of paintings there is an ornamental motive of a wrapped red and yellow ribbon.

\section{Conclusion}

The ornamentation of the church nave dominates the east wall. On the right side we can see the Virgin Mary with child, and above her the coat of arms of Ješek of Křižínkov. On the left side there is the painting of St. Catherine of Alexandria, with the iconic motif of a wheel, standing on the defeated 
Caesar. Above her there is a remainder of an alliance coat of arms, probably of the donor, with the decorative painting of a grapevine.

\section{References}

BISTŘICKÝ, J. 2002: Poznámka k tzv. zakládací listině třebičského kláštera.

Vlastivědný věstnik moravský 54, č. 3, 310-315.

DVOŘÁKOVÁ, K., SYSEL, F. 1997: Nástěnné malby v kostele sv. Krř́že v Nebovidech. Zprávy památkového ústavu v Brně 1/1997.

DVOŘÁKOVÁ, K., KUČERA, J., ZAVADIL, B. 2007: Neznámé poklady Moravy I. Obnovená matice moravská, Brno.

KLOBUŠICKÝ, J. 2004: Kult sv. Kateřiny Alexandrijské a jeho šírení. In: Kratochvílová, M. (Ed.): Znojemská rotunda, Malby v národní kulturní památce Rotunda sv. Kateřiny a výsledky současného výzkumu, Sborník z 2. konference o rotundě, konané 25. - 26. června 2003. Město Znojmo, Znojmo, 155-165.
PELÁN, J., 1983: Legenda o svaté Kateřině. Odeon, Praha.

MOJŽÍŠ, V., PTÁČKOVÁ, M., BARTL, L. 2004: Nebovidy 1104-2004. Petr Brázda, Břeclav.

SAMEK, B. 1999: Umélecké památky Moravy a Slezska 2. Academia, Praha.

PILŇÁČEK, J. 2004: Staromoravští rodové. Ottobre 12, Velehrad.

SPĚVÁČEK, J. 1979: Karel IV . Život a dílo (1316-1378). Svoboda, Praha.

ŠEBKOVÁ, A. 2007: Kostel v Nebovidech a jeho nástěnné malby, Filozofická fakulta Masarykovy univerzity, Brno.

ŠTĚPÁN, V. 2002: Moravský markrabě Jošt. Matice moravská, Brno.

VÍTOVSKÝ, J. 1999: Nástěnná malba v kostele sv. Kř́že v Nebovidech. Od gotiky k renesanci. Moravská galerie v Brně - Muzeum umění Olomouc, Brno.

de VORAGINE, J. 1984: Legenda aurea. E. Bahník, A. Vidinová (ed.), Vyšehrad, Pragae.

WOLNY, G. 1861: Kirchliche Topographie von Mähren, meist nach Urkunden und Handschriften 1. Georg Gastl's Buchdruckerei, Brünn. 